\title{
ANALISIS PENERAPAN KOMUNIKASI DAN PENGETAHUAN TENTANG KEBIJAKAN COVID-19 PADA KARYAWAN PERKANTORAN KEMENTERIAN KESEHATAN
}

\author{
Puspita Tri Utami $^{1}$, L. Meily Kurniawidjaja ${ }^{2}$ \\ Departemen Keselamatan dan Kesehatan Kerja, \\ Fakultas Kesehatan Masyarakat, Universitas Indonesia \\ puspita.tri@gmail.com¹, meilykurniawidjaja@gmail.com²
}

\begin{abstract}
Corona Virus Disease 19 or known as Covid-19 was declared a pandemic and a national disaster in early March 2020. The development of virus mutations with rapid transmission has increased confirmed cases of Covid-19. This increase in cases also occurred in office clusters, including the Ministry of Health. As a regulator of health problems, including in the prevention and control of Covid-19, it turns out that the office of the Ministry of Health of the positive confirmed cases of Covid-19 increased from rank 4 to rank 1 in the office cluster in DKI Jakarta even though the budget, policies and K3L committee (Occupational Safety and Health and Environment) are available. ) in the prevention and control of Covid-19. This study aims to analyze the application of Covid-19 policy communication and knowledge about Covid-19 policies to employees at the Ministry of Health Offices in 2021. The methodology used in this study is analytical observational with a cross sectional design of 440 employees from January 2021 to July 2021. Results Research shows positions, education and Covid-19 policy messages are related to Covid-19 policy knowledge. The application of effective communication is expected to increase the knowledge of the Ministry of Health office employees about the Covid-19 policy.
\end{abstract}

Keyword $\quad$ : Communication, knowledge, Covid-19 policy

\begin{abstract}
ABSTRAK
Corona Virus Disease 19 atau dikenal Covid-19 ditetapkan sebagai pandemic dan bencana nasional pada awal Maret 2020. Berkembangnya mutasi virus dengan penularannya cepat meningkatkan kasus terkonfirmasi Covid-19. Peningkatan kasus ini juga terjadi di cluster perkantoran termasuk Kementerian Kesehatan. Sebagai regulator permasalahan kesehatan termasuk dalam pencegahan dan pengendalian Covid-19 ternyata perkantoran Kementerian Kesehatan kasus terkonfirmasi positif Covid-19 meningkat dari peringkat 4 meningkat menjadi peringkat 1 cluster perkantoran di DKI Jakarta padahal tersedia anggaran, kebijakan dan komite Keselamatan dan Kesehatan kerja serta Lingkungan dalam pencegahan dan pengendalian Covid-19. Penelitian ini bertujuan untuk menganalisa penerapan komunikasi kebijakan Covid-19 dan Pengetahuan tentang Kebijakan Covid-19 pada karyawan di Perkantoran Kementerian Kesehatan Tahun 2021. Penelitian adalah observational analitik dengan studi potong lintang sebanyak 440 karyawan sejak Januari 2021 hingga Juli 2021. Hasil penelitian menunjukkan jabatan, pendidikan dan pesan berhubungan dengan pengetahuan kebijakan Covid-19. Penerapan komunikasi yang efektif diharapkan dapat meningkatkan pengetahuan karyawan perkantoran Kementerian Kesehatan tentang kebijakan Covid-19.
\end{abstract}

Kata Kunci : Komunikasi, pengetahuan, kebijakan Covid-19

\section{PENDAHULUAN}

Pada awal Maret 2020, Corona virus disease atau Covid-19 telah ditetapkan sebagai Pandemi. Penderita Covid-19 pada umumnya ditemukan gejala antara lain gangguan pernafasan akut seperti demam, batuk dan disertai sesak nafas (Menteri Kesehatan Republik Indonesia, 2020a). Secara umum perkantoran merupakan salah satu tempat kerja dengan ruangan tertutup dilengkapi dengan Air Conditioning (AC) dan disebutkan bahwa lingkungan yang tertutup dengan sirkulasi udara jelek dan 
tinggal kepadatan orang akan menjadi masalah dalam penyebaran Covid19(Bromage, 2020).

Kantor Kementerian Kesehatan merupakan suatu tempat yang membuat dan merumuskan norma, standar dan kebijakan dalam mengatasi semua permasalahan kesehatan yang ada di Indonesia termasuk pandemi COVID-19 serta memantau dan mengevaluasi pelaksanaan norma, standar dan kebijakan di daerah (Menteri Kesehatan Republik Indonesia, 2020b). Didapatkan dari hasil penilaian kantor berhias bulan Oktober 2020 ditemukan bahwa 12 dari 53 satuan kerja di Kementerian Kesehatan belum mengenal kebijakan internal tentang Covid19 yaitu SE Sekjen Nomor 3739 tahun 2020 tentang Upaya Pelaksanaan Keselamatan dan Kesehatan kerja serta Lingkungan (K3L) dalam pencegahan dan pengendalian Covid-19 di Lingkungan Kementerian Kesehatan. Semakin meningkatnya kasus Covid-19 di Indonesia ternyata kasus Covid-19 di Kantor Kementerian Kesehatan juga semakin meningkat dibuktikan dari data perkantoran di wilayah DKI Jakarta bulan Juni sampai Agustus 2020 (Covid19.go.id, 2021), Kantor Kementerian Kesehatan urutan ke-4 dari 68 perkantoran dan data bulan Agustus sampai Oktober 2020 urutan 1 dari 132 perkantoran. Sebelum peningkatan kasus Covid-19 di Kantor Kementerian Kesehatan telah membentuk Komite K3L sesuai SK Sekertaris Jenderal pada tanggal 9 Juli 2021. Diharapkan pembentukan Komite ini sebagai penggerak dalm pencegahan dan pengendalian Covid-19 dan penyampaian pesan tentang kebijakan Covid19. Hubungan atau ikatan yang menyatukan individu di suatu kelompok dalam suatu organisasi seperti Kementerian Kesehatan memerlukan komunikasi (Hardjana Andre, 2019).

Kebijakan yang dibuat oleh regulator melibatkan perilaku dengan suatu tujuan (Handoyo, 2012). Informasi berupa pengetahuan, media KIE, intervensi/pelatihan yang didapat melalui proses komunikasi merupakan salah satu factor yang mempengaruhi perilaku (Fishbein, 2011). Pengetahuan merupakan hasil tahu dari manusia dan ini terjadi setelah manusia mengadakan penginderaan terhadap suatu objek tertentu(Notoatmodjo, 2020). Faktor-faktor yang mempengaruhi pengetahuan antara lain Pendidikan, informasi, social,budaya, ekonomi, lingkungan dan usia (Budiman, 2013). Pembelajaran di tempat kerja oleh pekerja juga dipengaruhi oleh kontrol dan organisasi kerja meskipun pengalaman, ketrampilan, sikap, keyakinan sudah terbentuk sebelumnya (Fuller et al., 2005).

Di dalam Proses komunikasi terdapat pesan yang dikirim kemudian pesan diterima, individu akan berperilaku sesuai dengan pesan yang diterima (Hardjana Andre, 2019) (masalah). Unsur-unsur yang mempengaruhi komunikasi antara lain komunikator (Pemberi pesan), komunikan (penerima pesan), pesan (informasi/kebijakan) dan saluran/media (Notoatmodjo, 2019). Dalam komunikasi kebijakan, komunikator merupakan pengendali dari semua aktivitas komunikasi sehingga harus memenuhi tiga persyaratan yaitu tingkat kepercayaan orang lain, daya tarik dan kekuatan (Pricahyadi Moris, 2019), selain itu mempunyai pengetahuan, jujur, berpendidikan formal dan informal serta mengetahui tentang yang dikomunikasikan. Sedangkan komunikasi organisasi digunakan antara organisasi, institusi atau lembaga, unit komunikasi kelompok, atau suatu proses komunikasi internal dengan sesama karyawan, sesama atasan, atau atasan dan bawahan(Agustini \& Purnaningsih, 2018). Kementerian Kesehatan sebagai organisasi/institusi yang terkait kepentingan public sebaiknya berupaya membangun komunikasi public sehingga program akan tercapai. Citra organisasi di kalangan public tidak hanya berasal dari informasi yang didapatkan dari komunikasi public organisasi tetapi juga berasal dari pengalaman public yang berinteraksi (langsung dan tidak langsung) dengan kinerja organisasi, kualitas produk, 
jasa ataupun para karyawan organisasi. Baik komunikasi interpersonal, kelompok maupun organisasi mempunyai kemampuan mengembangkan encoding dan decoding dalam dirinya, mampu menyampaikan pesan dan mengartikan pesan yang diterima dari orang lain. Proses decoding merupakan penafsiran arti pesan, sedangkan encoding merupakan proses pengembangan pesan yang akan disampaikan ke orang lain (Hardjana Andre, 2019). Faktor utama dalam komunikasi tidak hanya pada apa yang ditulis atau diucapkan individu, tetapi lebih pada karakter individu dan bagaimana individu dapat mengirimkan/menyampaikan pesan kepada penerima pesan (Anatan, 2009). Terkait komunikasi peran pemimpin menentukan efektifitas komunikasi yang dipengaruhi kompetensi komunikasi melalui kualitas kepemimpinan dan implementasi efektifitas dan efisiensi keputusan dalam suatu organisasi. Komunikasi diikuti dengan proses manajemen sebagai kepemimpinan formal organisasi seperti perencanaan, pengorganisasian, dan kontrol. Tujuan strategi komunikasi yang efektif yang dilakukan adalah untuk memberikan pengaruh pada masyarakat termasuk di dalamnya pekerja, yaitu bentuk perubahan pengetahuan mempengaruhi bentuk perubahan persepsi, perubahan pendapat, dan bentuk perubahan sikap.(Pricahyadi Moris, 2019)

Di masa pandemi peranan komunikasi sangat penting terutama komunikasi risiko pada karyawan. Komunikasi risiko merupakan pertukaran informasi, pendapat dan saran dari para pakar, masyarakat serta pihak yang mempunyai kepentingan (WHO, 2020) dengan aktivitas membangun relasi dan pemahaman bersama dalam rangka terbentuknya kesadaran bersama akan risiko yang akan dihadapi (Damayanti, 2020). Kesadaran risiko adalah cara terbaik dalam mencegah dan memperlambat penularan COVID- 19 (Chatterjee et al., 2020). Tujuan penelitaian ini guna menganalisis hubungan antara penerapan komunikasi dan pengetahuan tentang kebijakan Covid-19 pada karyawan perkantoran Kementerian Kesehatan tahun 2021

\section{METODE}

Desain penelitian yaitu studi potong lintang (cross sectional), dianalisis dengan pendekatan semikuantitatif. Penelitian bertujuan untuk mengetahui hubungan antara variabel dependen (pengetahuan kebijakan Covid-19) dan beberapa variabel independen. Variabel dependen dan variable independen dalam penelitian ini diperoleh dengan menggunakan data primer yang dilakukan dengan pengisian assessmen kantor berhias oleh karyawan yang telah diuji validitas dan reliabilitas dimulai dari bulan Januari hingga Juli 2021. Sampel penelitian yaitu 440 karyawan ASN dan non ASN yang memenuhi kriteria inklusi (karyawan ASN dan Non ASN, usia 22-60 tahun) dan eksklusi (bekerja $<6$ bulan, tidak sehat jasmani dan rohani)

Hasil akan dianalisis secara deskriptif dan inferensial untuk melihat hubungan antara variabel independent dan variabel dependen. Analisis dilakukan untuk melihat gambaran atau distribusi frekuensi masing-masing variabel pada variabel kategorik akan digambarkan proporsi masing-masing kategori dan analisis hubungan antara masing-masing variabel dependen dan variable independent menggunakan uji hipotesis dengan Chi Square, derajat hubungan diketahui dari nilai Odds Ratio (OR). Penelitian ini telah mendapatkan persetujuan kaji etik dari Komisi Etik Riset dan Pengabdian kesehatan Masyarakat, Fakultas Kesehatan Masyarakat Universitas Indonesia Nomor : Ket- 346/UN2.F10.D11/PPM.00.02/2021

\section{HASIL}

Sebagian besar karyawan berusia dewasa muda (85,5\%), Non ASN $(56,6 \%)$, serta Pendidikan rendah $(47,2 \%)$. Pada Penerapan Komunikasi Internal terbanyak 
yaitu Saluran yang dipersepsikan baik $(89,5 \%)$, Frekuensi yang dipersepsikan baik (88,2\%), dan Pesan yang dipersepsikan baik $(90,9 \%)$. Informasi dan pengetahuan dari luar terbanyak didapatkan Sumber Informasi Karyawan Cukup (94,8\%), Frekuensi menerima Informasi karyawan Cukup $(71,6 \%)$ dan Isi/Materi karyawan Rendah(89,3\%). Sedangkan
Pengetahuan Kebijakan Internal Covid-19 pada karyawan terbanyak Buruk $(91,1 \%)$. Analisis inferensial Chi Square menunjukkan hubungan signifikan antara pesan, pendidikan, jabatan dan Pengetahuan Kebijakan Covid-19 dengan $\mathrm{p}$ value $<0,05$ (Tabel 2) dan masing-masing nilai $\mathrm{OR}=0,398$ (95\% CI: 0,163-0,972),

Tabel 1. Karakteristik Karyawan, Komunikasi Internal Kebijakan Covid-19, Informasi dan Pengetahuan Covid-19 Pada Karyawan Perkantoran Kementerian Kesehatan

\begin{tabular}{|c|c|c|c|}
\hline Variabel & Kategori & $n=440$ & Persentase $(100 \%)$ \\
\hline \multirow[t]{2}{*}{ Usia } & Dewasa Muda (22-45 th) & 376 & 85,5 \\
\hline & Dewasa Pertengahan (46-60 th) & 64 & 14,5 \\
\hline \multirow[t]{6}{*}{ Jabatan } & Non ASN & 250 & 56,6 \\
\hline & Pelaksana & 52 & 11,8 \\
\hline & Fungisional Pertama & 35 & 8 \\
\hline & Fungsional Muda & 69 & 15,7 \\
\hline & Fungsional Madya & 14 & 3,3 \\
\hline & Koordinator/Subkoordinator/Sturktural & 20 & 4,6 \\
\hline \multirow[t]{3}{*}{ Pendidikan } & Rendah (SMA) & 208 & 47,2 \\
\hline & Sedang (S1/D3/D4) & 121 & 27,5 \\
\hline & Tinggi (S2/S3) & 111 & 25,3 \\
\hline \multirow[t]{2}{*}{ Saluran } & Baik & 393 & 89,5 \\
\hline & Buruk & 47 & 10,5 \\
\hline \multirow[t]{2}{*}{ Frekuensi } & Baik & 387 & 88,2 \\
\hline & Buruk & 53 & 11,8 \\
\hline \multirow[t]{2}{*}{ Pesan } & Baik & 401 & 90,9 \\
\hline & Buruk & 39 & 9,1 \\
\hline \multirow{2}{*}{$\begin{array}{l}\text { Pengetahuan Kebijakan } \\
\text { Internal Covid-1i }\end{array}$} & Tinggi & 39 & 8,9 \\
\hline & Rendah & 401 & 91,1 \\
\hline \multirow[t]{2}{*}{ Sumber informasi } & Cukup & 417 & 94,8 \\
\hline & Kurang & 23 & 5,2 \\
\hline \multirow{2}{*}{$\begin{array}{l}\text { Frekuensi menerima } \\
\text { Informasi }\end{array}$} & Cukup & 316 & 71,6 \\
\hline & Kurang & 124 & 28,6 \\
\hline \multirow[t]{2}{*}{ Isi/Materi } & Tinggi & 46 & 10,7 \\
\hline & Rendah & 394 & 89,3 \\
\hline
\end{tabular}

Tabel 2. Hubungan Saluran/media, Frekuensi, Pesan, Materi informasi, Sumber Informasi, Frekuensi Menerima Informasi dan Pengetahuan Kebijakan Covid-19

\begin{tabular}{|c|c|c|c|c|c|}
\hline \multirow[t]{2}{*}{ Variabel } & \multicolumn{2}{|c|}{ Pengetahuan } & \multirow[t]{2}{*}{ Total } & \multirow[t]{2}{*}{ Odds Ratio } & \multirow{2}{*}{$\begin{array}{l}\text { Pearson } \\
\text { Chi } \\
\text { Square } \\
\mathrm{P}\end{array}$} \\
\hline & Rendah & Tinggi & & & \\
\hline \multicolumn{6}{|c|}{ Saluran/Media } \\
\hline Buruk & ; $(93 \%)$ & $3(7 \%)$ & $46(100 \%)$ & 1.445 & 0.552 \\
\hline Baik & $357(91 \%)$ & $37(9 \%)$ & $394(100 \%)$ & $(0.427-4.894)$ & \\
\hline \multicolumn{6}{|l|}{ Frekuensi } \\
\hline Buruk & $49(94 \%)$ & $3(6 \%)$ & $52(100 \%)$ & 1.675 & 0.4 \\
\hline
\end{tabular}




\begin{tabular}{|c|c|c|c|c|c|}
\hline Baik & $351(90 \%)$ & $37(9 \%)$ & $388(100 \%)$ & $(0.497-5.647)$ & \\
\hline \multicolumn{6}{|l|}{ Pesan } \\
\hline Buruk & $32(82 \%)$ & $7(18 \%)$ & $39(100 \%)$ & 0.398 & 0.037 \\
\hline Baik & $368(92 \%)$ & $33(8 \%)$ & $401(100 \%)$ & $(0.163-0.972)$ & \\
\hline \multicolumn{6}{|l|}{ Materi informasi } \\
\hline Rendah & $361(92 \%)$ & $32(8 \%)$ & $393(100 \%)$ & 2.025 & 0.111 \\
\hline Tinggi & $39(83 \%)$ & $8(17 \%)$ & $47(100 \%)$ & $(0.838-4.892)$ & \\
\hline \multicolumn{6}{|l|}{ Sumber Informasi } \\
\hline Kurang & $21(91 \%)$ & $2(9 \%)$ & $23(100 \%)$ & 2.106 & 0.463 \\
\hline Cukup & $379(91 \%)$ & $38(9 \%)$ & $417(100 \%)$ & $(0.276-16.09)$ & \\
\hline \multicolumn{6}{|c|}{ Frekuensi Menerima Informasi } \\
\hline Kurang & $289(93 \%)$ & $24(7 \%)$ & $313(100 \%)$ & 1.6270 & 0.158 \\
\hline Cukup & $111(87 \%$ & $16(13 \%)$ & $127(100 \%)$ & $(0.823-3.216)$ & \\
\hline \multicolumn{6}{|l|}{ Tingkat Pendidikan } \\
\hline Rendah & $199(96 \%)$ & $8(4 \%)$ & $207(100 \%)$ & 1.952 & 0.002 \\
\hline Sedang & $106(88 \%)$ & $15(12 \%)$ & $121(100 \%)$ & $(1.305-2.918)$ & \\
\hline Tinggi & $95(85 \%)$ & $17(15 \%)$ & $112(100 \%)$ & & \\
\hline \multicolumn{6}{|l|}{ Usia } \\
\hline Dewasa Muda & $346(92 \%)$ & $30(8 \%)$ & $376(100 \%)$ & 1.922 & 0.103 \\
\hline Dewasa Ptgh & $54(84 \%)$ & $10(16 \%)$ & $64(100 \%)$ & $(0.865-4.270)$ & \\
\hline \multicolumn{6}{|l|}{ Jabatan } \\
\hline Non ASN & $237(95 \%)$ & $12(5 \%)$ & $249(100 \%)$ & 1.421 & 0.004 \\
\hline Pelaksana & $45(86 \%)$ & $7(14 \%)$ & $52(100 \%)$ & $(1.174-1.719)$ & \\
\hline Jabfung Pertama & $32(91 \%)$ & $3(9 \%)$ & $35(100 \%)$ & & \\
\hline Jabfung Muda & $60(87 \%)$ & $9(13 \%)$ & $69(100 \%)$ & & \\
\hline Jabfung Madya & $11(73 \%)$ & $4(17 \%)$ & $15(100 \% 0$ & & \\
\hline Koordinator/struktural & $15(75 \%)$ & $5(25 \%)$ & $20(100 \%)$ & & \\
\hline
\end{tabular}

\section{PEMBAHASAN}

Berdasarkan hasil penelitian didapatkan bahwa tingkat pengetahuan kebijakan Covid-19 dan informasi Covid19 pada Karyawan Kementerian Kesehatan adalah buruk. Jika dilihat berdasarkan signifikasi hubungan, variable pesan kebijakan covid-19 dan jabatan juga merupakan variable yang memiliki hubungan terhadap pengetahuan kebijakan Covid-19.

Komunikasi merupakan suatu proses kehidupan dasar yang tidak terlihat dan hasilnya sulit diprediksi, terdapat pesan yang dikirim kemudian pesan diterima, orang akan bersikap sesuai dengan pesan, dimana individu di dalam kelompok, organisasi maupun masyarakat membuat dan menggunakan pesan ini untuk berhubungan satu sama lain dengan lingkungan(D.Rubent Brent, 2017). Dalam menerima pesan, komunikan dipengaruhi oleh kebutuhan, sikap, keyakinan, nilai, tujuan, kemampuan, gaya komunikasi komunikator, pengalaman dan kebiasaan. Pesan dapat diterima oleh komunikan dipengaruhi antara lain asal pesan, cara yang dipakai (visual, sentuhan, pendengaran, pengecapan atau penciuman), karakteristik pesan (ukuran, warna, intensitas), pengorganisasian pesan, kebaruan (informasi, bahasa), pengiriman pesan (kecepatan berbicara, volume, 
ekspresi wajah, gerak tubuh), pemilikan status (posisi, tingkatan )(D.Rubent Brent, 2017). Komunikasi organisasi menuntut kompetensi komunikasi pada jajaran manajemen dalam hal ini pimpinan dan komite K3L yang telah dibentuk terdapat saling percaya dan terbuka (Hardjana Andre, 2019), sehingga adanya system birokrasi di Kementerian Kesehatan yang masih menganut gaya kepemimpinan mewakilkan didapat pada penelitian Prof Udai Pareek, 1986 harus bergeser menjadi gaya kepemimpinan kolaborasi (mewakilkan dan menyertakan) apalagi saat ini era jabfung dituntut kompeten dan professional. Disamping itu perencanaan dan pengawasan diperlukan(Hardjana Andre, 2019) sehingga proses komunikasi kebijakan Covid 19 akan efektif.

Di dalam system birokrasi jabatan merupakan salah satu status social yang mempengaruhi pengetahuan karyawan. Jabatan pelaksana dan non ASN merupakan jabatan kurang dituntut professional dan kompeten dalam kinerja sehingga akan mempengaruhi frekuensi mencari sumber informasi dan dampaknya pengetahuan serta informasi yang didapat rendah dibuktikan dengan nilai $\mathrm{p}=0,004(\mathrm{p}<0,05)$. Hal ini akan mempengaruhi citra Kementerian Kesehatan sebagai pelaku komunikasi public suatu kebijakan karena karyawan adalah pemangku internal yang juga berperan sebagai komunikator tidak hanya sebagai komunikan (Hardjana Andre, 2019).

Komunikasi kebijakan yang efektif dapat memberikan motivasi karyawan (kebutuhan akan kebijakan) dan pembelajaran di tempat kerja oleh pekerja juga dipengaruhi oleh kontrol dan organisasi kerja meskipun pengalaman, ketrampilan, sikap, keyakinan sudah terbentuk sebelumnya)(Fuller et al., 2005). Seseorang danggap memiliki rasa efikasi diri yang tinggi dalam hubungannya untuk melakukan suatu perilaku jika mereka yakin bahwa mereka memiliki kualitas (kemampuan/ketrampilan) yang memungkinkan mereka berhasil melakukan perilaku (Fishbein, 2011). Selain itu diperlukan juga aturan komunikasi yang menyebutkan apa yang harus dilakukan, perilaku karyawan dapat dievaluasi, diberi reward atau sanksi (Hardjana Andre, 2019). Sifat yang penting dalam komunikasi organisasi antara lain penciptaan pesan, penafsiran, dan dalam penanganan kegiatan anggota organisasi (Agustini \& Purnaningsih, 2018). Penafsiran atau persepsi individu dipengaruhi oleh pendidikan individu tersebut yang nantinya akan berpengaruh pada tingkat pengetahuannya (Notoatmodjo, 2020). Hal ini dibuktikan dengan nilai $\mathrm{p}$ pendidikan $=$ $0,002(\mathrm{p}<0,05)$. Instansi perlu menerapkan komunikasi risiko, yaitu pemahaman bersama dalam rangka terbentuknya kesadaran bersama akan risiko yang dihadapi selama pandemic (Damayanti, 2020) akan membatasi penularan Covid-19 sebagai tujuan kebijakan.

Pesan-pesan kebijakan yang disampaikan oleh Kementerian Kesehatan kemungkinan belum tercapai di masyarakat karena di dalam internal Kementerian Kesehatan belum maksimal penerapan kebijakan yang disebabkan kurangnya motivasi, kurangnya kompetensi dan belum dilakukan strategi komunikasi yang efektif, dibuktikan pesan kebijakan nilai $\mathrm{p}=0.037$ $(p<0,05)$. Hal ini juga sesuai dengan penelitian (Pricahyadi Moris, 2019) yaitu para pimpinan di unit kerja belum sepenuhnya mempunyai komitmen untuk mewujudkan komunikasi dalam bentuk kata-kata dan perilaku, perilaku dari aparatur pemerintahan sebagian besar belum konsisten dengan kebijakan dan perkataan, ditemukan masih banyaknya program yang tidak efektif pada komunikasi di bawah dan belum tercapainya suatu kesepakatan dalam pemanfaatan komunikasi interpersonal. Penelitian lain tentang kebijakan ternyata tidak semua pekerja sebagai warga negara secara penuh mematuhi kebijakan Covid19 karena secara keseluruhan puas dengan tanggapan pemerintah terhadap pandemic Covid-19 tetapi tidak setuju terhadap 
langkah-langkah tindakan kebijakan (Sabat et al., 2020) sehingga evaluasi terhadap pesan-pesan kebijakan perlu dilakukan.

\section{KESIMPULAN}

Pada penelitian ini didapatkan ada pengaruh yang signifikan antara jabatan, pesan kebijakan Covid-19, pendidikan dan pengetahuan kebijakan Covid 19. Pengetahuan karyawan (dari setiap jabatan) tentang kebijakan Covid-19 dan informasi Covid-19 masih rendah. Kantor Kementerian Kesehatan memiliki perangkat seperti komite sebagai penggerak tetapi tim tersebut belum melaksanakan tugasnya secara maksimal dalam pencegahan dan pengendalian Covid-19.

\section{UCAPAN TERIMA KASIH}

Peneliti mengucapkan terima kasih kepada seluruh pihak yang terlibat dalam penelitian diantaranya Instansi Kementerian Kesehatan, pembimbing akedemik Prof. Dr. dr. L. Meily Kurniawidjaja, M.Sc., Sp. Ok yang telah memberikan arahan dan membantu dalam proses penelitian ini serta karyawan Kementerian Kesehatan sebagai responden, serta semua pihak yang membantu hingga penerbitan dapat dilakukan dengan sempurna.

\section{DAFTAR PUSTAKA}

Agustini, N. A., \& Purnaningsih, N. (2018). Pengaruh Komunikasi Internal dalam Membangun Budaya Organisasi. Jurnal Komunikasi Pembangunan, 16(1), 89-108. https://doi.org/10.46937/1620182519 8

Anatan, L. (2009). Efektiviasi Komunikasi dalam Organisasi. 7(4), 1-9.

Bromage, E. (2020). The Risks - Know Them - Avoid Them. In Erinbromage.Com (pp. 1-12). https://www.erinbromage.com/post/th e-risks-know-them-avoid-them

Budiman. (2013). Kapita Selekta Kuesioner:Pengetahuan dan Sikap dalam Penelitian Kesehatan. Salemba Medika.

Chatterjee, R., Bajwa, S., Dwivedi, D., Kanji, R., Ahammed, M., \& Shaw, R. (2020). COVID-19 Risk Assessment Tool: Dual application of risk communication and risk governance. Progress in Disaster Science, 7, 100109.

https://doi.org/10.1016/j.pdisas.2020. 100109

Covid19.go.id. (2021). Peningkatan Cluster Perkantoran di DKI Jakarta.

D.Rubent Brent. (2017). Komunikasi dan Perilaku Manusia (kelima). Rajawali Press.

Damayanti, A. (2020). Instagram sebagai Medium Komunikasi Risiko di Masa Pandemi COVID-19: Studi Netnografi terhadap Komunitas Online KawalCOVID19.id. Jurnal Komunikasi Pembangunan, 18(02), 176-193. https://doi.org/10.46937/1820203235 5

Fishbein. (2011). Predicting and Changing Behaviour. Psychology Press.

Fuller, A., Hodkinson, H., Hodkinson, P., \& Unwin, L. (2005). Learning as peripheral participation in communities of practice: A reassessment of key concepts in workplace learning. British Educational Research Journal, 31(1), 49-68.

https://doi.org/10.1080/01411920520 00310029

Handoyo, E. (2012). Kebijakan Publik. Kebijakan Publik Deliberatif, 9.

Hardjana Andre. (2019). Komunikasi Organisasi: Strategi Interaksi dan Kepemimpinan (pertama). Rajawali Press.

kemenkes.go.id. (2021). Virus Corona Varians Baru B.117, B.1351, B.1671).

Kurniawidjaja. (2020). Teori dan Aplikasi Promosi Kesehatan di Tempat Kerja. 
Universitas Indonesia.

Menteri Kesehatan Republik Indonesia.

(2020a). Keputusan Menteri

Kesehatan Republik Indonesia Nomor HK.01.07/MenKes/413/2020 Tentang

Pedoman Pencegahan dan

Pengendalian Corona Virus Disease 2019 (Covid-19). MenKes/413/2020, 2019, 207.

Menteri Kesehatan Republik Indonesia. (2020b). Organisasi dan Struktur Organisasi Kementerian Kesehatan. 2507(February), 1-9.

Notoatmodjo. (2019). Promosi Kesehatan dan Perilaku Kesehatan. Rineka Cipta.

Notoatmodjo. (2020). Ilmu Perilaku Kesehatan (2nd ed.). Rineka Cipta.

Pricahyadi Moris. (2019). Pengembangan,
Media Administrasi, Praktek Gubernur, Peraturan Tahun, Nomor. Jutnal Ilmu Administrasi (JIA), XVI(1), 112-126.

Sabat, I., Neuman-Böhme, S., Varghese, N. E., Barros, P. P., Brouwer, W., van Exel, J., Schreyögg, J., \& Stargardt, T. (2020). United but divided: Policy responses and people's perceptions in the EU during the COVID-19 outbreak. Health Policy, 124(9), 909918.

https://doi.org/10.1016/j.healthpol.20 20.06.009

WHO. (2020). Risk communications. 